\title{
College students' happiness personality attitude and correlation analysis of physical exercise
}

\author{
Xingsheng Zhang ${ }^{\mathrm{a}}$ and Hejian Yang \\ The Basic Dept, Lianyungang Technical College, Lianyungang 222006, China
}

\begin{abstract}
An empirical analysis in this paper, the frequency of exercise, exercise intensity and exercise time according to the option of the survey, analyze the motivation of college students based on exercise sample $\mathrm{T}$ test results, are analyzed based on different genders, different students, different personality attitude subject categories and whether belong to one child policy differences $\mathrm{T}$ test results, the analysis was based on different gender, different students and whether happiness belong to one child policy differences $T$ test results, are analyzed based on different exercise intensity, exercise time and different frequency of subjective well-being and personality attitude the correlation of test results.
\end{abstract}

\section{Introduction}

University students subjective well-being and personality attitude have great differences, such as different genders, different students origins and different disciplines, they have great differences, but how to eliminate such differences and make contributions to healthy university students personality building are of people general concerns. Someone guesses that applies physical exercises method to improve university students' subjective well-being and personality attitude, the paper takes this as base point, explores the three relations, in the hope of making contributions to university students healthy growth [1-3].

The paper on the basis of former researches, explores university student subjective well-being and personality attitude as well as physical exercises relations, with an aim to provide theoretical basis for physical exercise being capable of improving university students subjective well-being and personality attitude.

\section{Overview of physical exercises, well-being and personality attitude}

Physical exercises can make classification according to ways as following:

1) Classify according to exercises participants, in this way, it can divide into collective exercises and individual exercises.

2) Classify according to exercises process human physiological metabolism features, in this way, it can divide into aerobics, anaerobics and combinative aerobics and anaerobics such three kinds.

3) Classify according to physical exercises events feedback features, in this way, it can divide into open technology and closed technology two kinds, the later needs to make feedback adjustment relying on internal and ontic sense organs.

4) Classify according to physical exercises competitiveness, in this way, it can divide into entertainment sports and competitive sports, the former exercise purpose is build body and for pleasure, the later exercise purpose is to pursuit highest, furthest and strongest.

Physical exercises have a variety of kinds, sportsman should make exercise standardization according to one's own different demands, evaluate physical exercises standard variables normally use exercise intensity, exercise frequency, exercise duration and sports population the four to make comprehensive analysis, in the following, it overviews above four variables, in the hope of providing scientific evaluation carrier for physical exercises behaviors well-being differences and personality attitude differences under different dimensions [4].

1) Exercise intensity: The variable often uses heart rate, pulse or blood pressure such kinds of physiological indicators to make evaluation, in order to make classification of exercise intensity, the paper thinks that when breath and heartbeat little change and its highest heart rate is around $60 \%$, it is the small intensity, while breath and heartbeat get faster and highest heart rate is between $65 \% \sim 70 \%$, it is medium intensity, and breath and heartbeat changes very fast and sweat more as well as heart rate arrives at $80 \% \sim 90 \%$, it is high intensity.

2) Exercise frequency: The variable often uses exercise durations per week to measure.

3) Exercise duration: The variable often uses physical exercise schedule rationality and exercise duration per

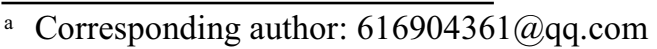


time to measure.

4) Sports population: Measurement of the variable is a number, judgment of sports population can carry on accord physical activities arrive at above three times per week, physical activities time is above 30 minutes per time and physical activities intensity arrives at medium and strong intensity criterion, when people simultaneously meet above three conditions, he is supposed to a member in sports population. Personality attitude uses people positive and optimistic mental states to present, and optimism is a kind of important positive experience, is a kind of explanation style not general personality features. Many researches how two factors model has better distinguish effects on physical health status and emotion status prediction, effects merits have been verified by structural equation model by someone.

\section{Research objects and research methods}

\subsection{Research objects}

The paper selected research objects are from one province four universities sophomore students, total sample size is 440 ; it makes investigation on research objects daily physical exercise, well-being and personality attitude.

Research objects can use gender, students origin, single child or not and located major and discipline type to make classification, according to above classification, students amount basic information is as Table 1 shows.
Research objects each sports event number of people basic status and different exercises ways status are as Table 2 shows.

\subsection{Research methods}

In the paper, it adopts document literature, questionnaire survey and mathematical statistics.

1) Documents literature

The paper searches from China national knowledge internet 10 pieces of periodical literatures about university students physical exercises researches, 12 pieces of periodical literatures about university students physical exercises and well-being correlation researches, and 8 pieces of periodical literatures about university students physical exercises and personality attitude correlation researches, which provides theoretical basis and research orientations for the paper researching.

2) Questionnaire survey

The paper adopts "physical exercises questionnaire" to investigate on research objects exercises purposes, exercise events, exercises participation constraint main factors, exercises history, exercises ways at ordinary times, exercise intensity, exercise frequency and exercise duration eight aspects contents.

Apply "General well-being schedule" to make investigate on research objects health concerns, vigor, satisfaction and interests on life, melancholy or pleasure mood, controlling of emotion and behaviors as well as relaxed and tight theses six aspects.

Table 1. Research objects sample size classification basic information table.

\begin{tabular}{|c|c|c|c|c|c|c|}
\hline $\begin{array}{c}\text { Classification } \\
\text { criterion }\end{array}$ & Type & Quantity & Percentage & $\begin{array}{l}\text { Exercises } \\
\text { amount }\end{array}$ & $\begin{array}{c}\text { Non } \\
\text { exercise } \\
\text { amount }\end{array}$ & Percentage \\
\hline \multirow{2}{*}{ Gender } & Men & 146 & $33.18 \%$ & 186 & 35 & $84.16 \%$ \\
\hline & Women & 294 & $66.82 \%$ & 180 & 39 & $82.19 \%$ \\
\hline \multirow{2}{*}{$\begin{array}{l}\text { Origin of } \\
\text { students }\end{array}$} & City & 194 & $44.09 \%$ & 158 & 42 & $79.00 \%$ \\
\hline & Country & 246 & $55.91 \%$ & 208 & 32 & $86.67 \%$ \\
\hline \multirow{2}{*}{$\begin{array}{l}\text { Single child } \\
\text { or not }\end{array}$} & Single child & 263 & $59.77 \%$ & 176 & 41 & $81.11 \%$ \\
\hline & $\begin{array}{l}\text { Non-single } \\
\text { child }\end{array}$ & 177 & $40.23 \%$ & 190 & 33 & $85.20 \%$ \\
\hline \multirow[b]{2}{*}{$\begin{array}{l}\text { Discipline } \\
\text { type }\end{array}$} & $\begin{array}{l}\text { Literature and } \\
\text { history type }\end{array}$ & 208 & $47.27 \%$ & 163 & 45 & $78.37 \%$ \\
\hline & $\begin{array}{l}\text { Science and } \\
\text { engineering } \\
\text { type }\end{array}$ & 232 & $52.73 \%$ & 203 & 29 & $87.50 \%$ \\
\hline
\end{tabular}

Table 2. Research objects different exercises ways basic status table.

\begin{tabular}{|c|c|c|c|c|c|c|c|}
\hline Sports event & Men \% & Women \% & Sports event & Men \% & Women \% & $\begin{array}{c}\text { Exercises } \\
\text { ways }\end{array}$ & $\begin{array}{c}\text { Number of } \\
\text { people } \%\end{array}$ \\
\hline Basketball & $25.5 \%$ & Jogging & $19.8 \%$ & $20.3 \%$ & With friends & $25.68 \%$ & $3.4 \%$ \\
\hline Badminton & $18.6 \%$ & $19.9 \%$ & Aerobics & $7.9 \%$ & $10.8 \%$ & $\begin{array}{c}\text { With } \\
\text { classmates }\end{array}$ & $39.09 \%$ \\
\hline Table tennis & $11.3 \%$ & $6.5 \%$ & Swimming & $6.7 \%$ & $8.9 \%$ & With family & $8.86 \%$ \\
\hline Football & $6.5 \%$ & $0.6 \%$ & Yoga & $0.0 \%$ & $9.3 \%$ & Alone & $21.36 \%$ \\
\hline $\begin{array}{c}\text { Rope } \\
\text { skipping }\end{array}$ & $0.0 \%$ & $17.7 \%$ & Others & $3.7 \%$ & $2.6 \%$ & Others & $5.00 \%$ \\
\hline
\end{tabular}


Table 3. Exercise frequency, exercise duration and exercise intensity investigation result table $(\mathrm{N}=440)$.

\begin{tabular}{|c|c|c|c|c|c|c|}
\hline \multicolumn{4}{|c|}{ Exercise duration } & \multicolumn{3}{|c|}{ Exercise intensity } \\
\hline \multicolumn{2}{|c|}{ Option setting } & Quantity & Percentage & Option setting & Quantity & Percentage \\
\hline \multicolumn{2}{|c|}{$t<10 \min$} & 14 pieces & $3.18 \%$ & Slightly exercise & 35 pieces & $7.95 \%$ \\
\hline \multicolumn{2}{|c|}{$11<t<20 \min$} & 53 pieces & $12.05 \%$ & $\begin{array}{l}\text { Little intensity } \\
\text { exercises }\end{array}$ & 98 pieces & $22.27 \%$ \\
\hline \multicolumn{2}{|c|}{$21<t<30 \mathrm{~min}$} & 94 pieces & $21.36 \%$ & $\begin{array}{c}\text { Moderate } \\
\text { intensity and } \\
\text { enduring }\end{array}$ & 139 pieces & $24.77 \%$ \\
\hline \multicolumn{2}{|c|}{$31<t<59 \min$} & 125 pieces & $28.41 \%$ & $\begin{array}{l}\text { Heavy intensity } \\
\text { not enduring }\end{array}$ & 137 pieces & $31.14 \%$ \\
\hline \multicolumn{2}{|c|}{$60<t$} & 154 pieces & $35.00 \%$ & $\begin{array}{l}\text { Heavy intensity } \\
\text { and enduring }\end{array}$ & 31 pieces & $7.05 \%$ \\
\hline \multirow{6}{*}{$\begin{array}{l}\text { Exercise } \\
\text { frequency }\end{array}$} & \multicolumn{2}{|c|}{ Option setting } & $\begin{array}{c}\text { Number of } \\
\text { men }\end{array}$ & Men percentage & $\begin{array}{c}\text { Number of } \\
\text { women }\end{array}$ & $\begin{array}{c}\text { Women } \\
\text { percentage }\end{array}$ \\
\hline & \multicolumn{2}{|c|}{$\begin{array}{l}\text { Once or below per } \\
\text { month }\end{array}$} & 13 pieces & $2.95 \%$ & 29 pieces & $6.59 \%$ \\
\hline & \multicolumn{2}{|c|}{$\begin{array}{l}\text { Twice to third times } \\
\text { per month }\end{array}$} & 45 pieces & $10.24 \%$ & 59 pieces & $13.41 \%$ \\
\hline & \multicolumn{2}{|c|}{$\begin{array}{l}\text { Once to twice per } \\
\text { week }\end{array}$} & 83 pieces & $18.86 \%$ & 58 pieces & $13.18 \%$ \\
\hline & \multicolumn{2}{|c|}{$\begin{array}{l}\text { Third times to five } \\
\text { times per week }\end{array}$} & 65 pieces & $14.77 \%$ & 49 pieces & $11.14 \%$ \\
\hline & \multicolumn{2}{|c|}{$\begin{array}{l}\text { Six times and seven } \\
\text { times per week }\end{array}$} & 26 pieces & $5.91 \%$ & 13 pieces & $2.95 \%$ \\
\hline
\end{tabular}

Apply "Dispositional optimism questionnaire" to score on research objects with optimism and pessimism two dimensions, in the hope of scoring on research objects personality attitude.

In the hope of exploring positive effects that physical exercises bring to university students well-being index and physical exercises provided positive promotions to university students' personality by above three questionnaires data processing results and statistical test results.

The research released questionnaires are totally 500 pieces, its returning rate arrives at $100 \%$, from which physical exercises questionnaire an subjective well-being invalid questionnaires amount are totally 19 pieces, dispositional optimism questionnaire has 4 pieces of invalid questionnaires, and still 37 pieces of questionnaires unfulfilled are regarded as invalid questionnaires, so, questionnaire survey effective returning rate is $88 \%$ this time.

3) Mathematical statistics

In order to do data processing with effective return questionnaires, it adopts mathematical statistics method, data statistical amount calculation is fulfilled by statistical software SPSS, carries out independent sample T test, correlation analysis and single factor variance analysis of sample data group.

\section{Empirical analysis}

University students physical exercises participation frequency, exercise duration per time and exercise intensity investigation result is as Table 3 shows, research objects total sample size is 440 people, it appears in the form of percentage in the table that number of people percentage in total samples under the type [5].

By Table 3, it is clear that university student exercise duration below half an hour occupy $36.59 \%$ of totals, and university students that arrive at above 30 minutes exercise duration occupy $63.41 \%$ of totals, in the view of exercise duration, nearly 70 percent students can arrive at exercises effects. Under little intensity exercises, university students occupy $30.22 \%$ of totals, the part students exercise intensity is to be improved, students take moderate intensity and enduring exercises are $24.77 \%$, students take heavy intensity and non-enduring exercises are $31.14 \%$, only $7.05 \%$ students can insist on heavy intensity and enduring exercises, which shows most of students love moderate intensity exercises and heavy intensity but non-enduring exercises, it doesn't advocate heavy intensity and enduring exercises here. Schoolgirls that take exercises below third times per month occupy $20 \%$ of totals, the figure is relative pessimistic, it needs such part schoolgirls to improve their exercise frequency, exercise times arrive at above third times per week can be called as sports population, the part students occupy $34.77 \%$ of totals, from which schoolboys occupy $20.68 \%$, schoolgirls occupy $14.09 \%$, the figure is also not optimistic, which needs to be improved especially for schoolgirls.

University students physical exercises participation six kinds of motivation statistics result is as Table 4 shows, in Table 4, it shows option A. enhance communication、 B. build one's body、C. psychological adjustment、D. feel exercises are not enough,E. pass time and entertainment and F. beauty building and lose weight these six items number of people statistical result, and gives $T$ test value and the value corresponding significance probability $P$.

By Table 4 data, it is clear that university students physical exercises motivations from weak to strong are respectively psychological adjustment $<$ pass time and entertainment $<$ feel exercises are not enough $<$ enhance 
Table 4. Exercise motivation-based university students sample size $\mathrm{T}$ test result table $(\mathrm{N}=440)$.

\begin{tabular}{|c|c|c|c|c|c|c|c|}
\hline \multicolumn{2}{|c|}{ Exercise motivation } & \multicolumn{2}{|c|}{$\begin{array}{l}\text { Men and women totals } \\
\text { and percentage }\end{array}$} & \multicolumn{2}{|c|}{$\begin{array}{l}\text { Men amount and } \\
\text { percentage }\end{array}$} & \multicolumn{2}{|c|}{$\begin{array}{l}\text { Women amount and } \\
\text { percentage }\end{array}$} \\
\hline \multirow{7}{*}{$\begin{array}{c}\mathrm{T}= \\
0.241 \\
\mathrm{P}= \\
0.454\end{array}$} & Content & Sum total & Percentage & Amount & Percentage & Amount & Percentage \\
\hline & $\begin{array}{c}\text { Enhance } \\
\text { communication }\end{array}$ & 71 & $16.14 \%$ & 34 & $47.89 \%$ & 37 & $52.11 \%$ \\
\hline & Build one's body & 165 & $37.50 \%$ & 86 & $52.12 \%$ & 79 & $47.88 \%$ \\
\hline & $\begin{array}{l}\text { Psychological } \\
\text { adjustment }\end{array}$ & 24 & $5.45 \%$ & 11 & $45.83 \%$ & 13 & $54.17 \%$ \\
\hline & $\begin{array}{l}\text { Feel exercises } \\
\text { are not enough }\end{array}$ & 55 & $12.50 \%$ & 21 & $46.63 \%$ & 34 & $54.17 \%$ \\
\hline & $\begin{array}{l}\text { Pass time and } \\
\text { entertainment }\end{array}$ & 32 & $7.27 \%$ & 19 & $59.38 \%$ & 12 & $37.50 \%$ \\
\hline & $\begin{array}{l}\text { Beauty building } \\
\text { and lose weight }\end{array}$ & 93 & $21.14 \%$ & 43 & $46.24 \%$ & 50 & $53.76 \%$ \\
\hline
\end{tabular}

Table 5. Subjective well-being and personality attitude correlation test result table on the basis of physical exercises different intensity, time and frequency.

\begin{tabular}{|c|c|c|c|c|c|c|c|c|}
\hline \multirow{2}{*}{$\begin{array}{l}\text { Physical exercise } \\
\text { factor }\end{array}$} & \multicolumn{6}{|c|}{ Subjective well-being } & \multicolumn{2}{|c|}{$\begin{array}{l}\text { Personality } \\
\text { attitude }\end{array}$} \\
\hline & $\mathrm{A}$ & B & $\mathrm{C}$ & $\mathrm{D}$ & $\mathrm{E}$ & $\mathrm{F}$ & $\mathrm{G}$ & $\mathrm{H}$ \\
\hline $\begin{array}{l}\text { Different exercise } \\
\text { intensity }\end{array}$ & 0.034 & $-0.110^{*}$ & 0.067 & 0.000 & 0.054 & 0.046 & 0.039 & -0.032 \\
\hline $\begin{array}{l}\text { Different exercise } \\
\text { duration }\end{array}$ & 0.010 & -0.013 & 0.047 & 0.010 & $0.112^{*}$ & 0.026 & 0.065 & 0.052 \\
\hline $\begin{array}{l}\text { Different exercise } \\
\text { frequency }\end{array}$ & -0.016 & -0.040 & $0.099^{*}$ & 0.071 & 0.021 & 0.026 & 0.007 & 0.059 \\
\hline
\end{tabular}

communication $<$ beauty building and lose weight $<$ build one's body, from which build one's body and beauty building and lose weight motivations occupy 58.64\% of totals, in the motivation of feeling exercises are not enough, schoolgirls are higher than schoolboys, in the motivation of psychological adjustment, schoolgirls are also higher than schoolboys, but in pass time and entertainment, schoolboys are more than schoolgirls.

Subjective well-being relative test result and personality attitude relative test result based on different exercise intensity, different exercise duration and different exercise frequency are as Table 5 shows, add a "*” behind test value represents corresponding $\mathrm{P}$ value is less than 0.05 , add two "*” represents corresponding $\mathrm{P}$ value is less than 0.01 , add three "*" represents corresponding $\mathrm{P}$ value is less than 0.001 .

By Table 5 data, it is clear, in subjective well-being six factors, except for satisfaction and interests on life factor and health concerns factor, other four factors are in positive correlation with exercise intensity, exercise duration and exercise frequency, satisfaction and interests on life factor is in negative correlation with exercise frequency, while health concerns factor is in negative correlation with exercise intensity, exercise duration and exercise frequency; among them, exercise intensity and health concerns have significant differences, exercise frequency and vigor have significant differences, exercise duration and controlling of emotion and behaviors factor has significant differences. In Table 5, it also reflects that optimistic factor is in positive correlation with exercise intensity, exercise duration and exercise frequency, while pessimistic factor is in positive correlation with exercise duration and exercise frequency but in negative correlation with exercise intensity, personality attitude two factors have insignificant differences in exercise intensity, exercise duration and exercise frequency [6].

\section{Conclusions}

University student exercise duration below half an hour occupy $36.59 \%$ of totals, and university students that arrive at above 30 minutes exercise duration occupy $63.41 \%$ of totals, in the view of exercise duration, nearly 70 percent students can arrive at exercises effects. Under little intensity exercises, university students occupy $30.22 \%$ of totals, the part students exercise intensity is to be improved, students take moderate intensity and enduring exercises are $24.77 \%$, students take heavy intensity and non-enduring exercises are $31.14 \%$, only $7.05 \%$ students can insist on heavy intensity and enduring exercises, which shows most of students love moderate intensity exercises and heavy intensity but non-enduring exercises, it doesn't advocate heavy intensity and enduring exercises here. Schoolgirls that take exercises below third times per month occupy $20 \%$ of totals, the figure is relative pessimistic, it needs such part schoolgirls to improve their exercise frequency, exercise times arrive at above third times per week can be called as sports population, the part students occupy $34.77 \%$ of totals, from which schoolboys occupy $20.68 \%$, schoolgirls occupy $14.09 \%$, the figure is also not optimistic, which needs to be improved especially for schoolgirls. 
University students physical exercises motivations from weak to strong are respectively psychological adjustment $<$ pass time and entertainment $<$ feel exercises are not enough $<$ enhance communication $<$ beauty building and lose weight $<$ build one's body, from which build one's body and beauty building and lose weight motivations occupy $58.64 \%$ of totals, in the motivation of feeling exercises are not enough, schoolgirls are higher than schoolboys, in the motivation of psychological adjustment, schoolgirls are also higher than schoolboys, but in pass time and entertainment, schoolboys are more than schoolgirls.

\section{References}

1. J.Q. Liu, Journal of Pla Institute of Physical Education 30 (2011).

2. J.L. Ning, Bulletin of Sport Science \& Technology, 21 (2013).

3. Y. Li, C.H. Huang, Journal of Sports Adult Education 27 (2011).

4. D.Z. Shi, G. Yang, Journal of Hubei Sports Science, 32 (2013).

5. H. Cheng, F. Li, Q. Mao, Journal of Coastal Research 73 (2015).

6. J. Wang, Z.L. Liu, Y. Chen, AISS: Advances in Information Sciences and Service Sciences 4, 14 (2012). 